\title{
Dr. Eduardo Luna Ramia
}

\section{Sarah González de Lora Translated by Patrick (Rick) Scott}

Dr. Eduardo Luna passed away on April 26, 2019. Dr. Luna was a pioneer in mathematics and mathematics education in the Dominican Republic. He created new programs, encouraged international cooperation, and was a founding member of both the Mathematical Society of the Dominican Republic (SOMAREDO) and the Academy of Sciences of the Dominican Republic. In this short remembrance, we look back at the multitude of ways that he contributed to math education in the Dominican Republic and throughout Latin America.

Dr. Luna was born on January 30, 1938 in Santiago de los Caballeros, Dominican Republic. He went to elementary school at the Colegio De La Salle. His secondary education was completed in Cuba in 1958 at the Institute of Secondary Education in Havana. He pursued a bachelor's degree in mathematics-physics at the University of Havana until 1961, when he had to move to the United States.

He went to graduate school in mathematics at the Catholic University of America, completing a master's degree in 1966 with a thesis entitled "The Strong Law of Large Numbers investigated from the works of E. Borel to Y. V. Prokhorov." After a three-year break, he returned to the Catholic University to obtain his PhD in 1973, with a dissertation entitled "Existence of solutions for generalized Cauchy-Goursat type problems for hyperbolic equations." He was one of 14 students who wrote their dissertation under the direction of Victor Michael Bogdan. Dr. Luna's areas of interest in mathematics were real analysis, measure theory and integration, ordinary differential equations, and

Sarah González de Lora is a professor of mathematics at the Pontificia Universidad Católica Madre y Maestra (PUCMM). Her email address is sarahgonzalez@pucmm.edu.do.

Patrick (Rick) Scott is a professor emeritus at New Mexico State University. His email address is pscott@nmsu.edu.

Communicated by Notices Associate Editor William McCallum.

For permission to reprint this article, please contact: reprint-permission aams.org.

DOI: https://dx.doi.org/10.1090/noti 2332 partial differential equations. In addition, he was always deeply interested in math education.

In January 1973, he returned to the Dominican Republic as a professor in the Department of Mathematics at the Pontifical Catholic University Madre y Maestra (PUCMM). He worked there until 1989, reaching the rank of full professor and distributing his time between teaching, research, and administration. As a professor, he was well known for the clarity of his presentations, his conceptual precision, and the cordial atmosphere with which he socialized with his students. All of these characteristics made him one of the most distinguished and appreciated teachers at the University, as demonstrated by the excellent evaluations he got from his students and colleagues.

In 1989, he joined the faculty at Barry University, in Miami Shores, Florida, with the rank of professor. Ten years later he was appointed chair of the Mathematics Department. He remained at Barry University until retiring in 2008.

Throughout his career, Dr. Luna was active in numerous organizations and programs devoted to mathematics education. In 1975, he was invited to speak at the IVth Inter-American Conference on Mathematics Education (IACME IV) held in Caracas, Venezuela. After that, he became involved with various aspects of IACME. In particular, from 1975 to 1978, he was the Dominican Republic representative to the IACME, and from 1987 to 1995 he was the president of the IACME. In 1987 he led the organization of the IACME VII conference in Santo Domingo. His role in the IACME enabled him to participate in numerous important mathematics education activities in Latin America in the years that followed.

In 1978 in Caracas, Venezuela, Dr. Luna participated in the Second International Study of Mathematics (SIMS) where representatives from Latin American countries came together to discuss issues in math education. Later, Dr. Luna led a replication of SIMS (Population A, eighth grade students in the Dominican Republic) at the PUCMM 
Research Center. This program was the beginning of a series of research and development projects sponsored by the Canadian International Development and Research Center (IDRC), the Canadian International Development Agency (CIDA), and PUCMM, which were completed in 1992. These projects included in-service teacher training and the creation of mathematics teaching materials at the elementary and secondary levels. Dr. Luna collaborated on related projects funded by the United States Agency for International Development (USAID) for as long as his health allowed.

Eduardo Luna made outstanding contributions to several of the International Congresses on Mathematical Education (ICME). He was elected as a member of the Executive Committee of the International Commission on Mathematics Instruction (ICMI) of the International Mathematical Union for 1991-1994. He also was a member of the Task Force of the Third International Mathematics and Science Study (TIMSS) and encouraged Latin American participation in TIMSS.

In 1998, he received funding from ICMI to prepare and publish in Spanish and English The History of the Inter-American Committee on Mathematics Education written by Angel Ruiz and Hugo Barrantes (University of Costa Rica). That same year he joined the work of ICMI to plan the World Mathematical Year 2000. While he was serving in that capacity, he directed the celebration of the XIII Ibero-American Mathematics Olympiad, which took place in September 1998 in Puerto Plata, Dominican Republic.

Eduardo Luna also played an important role in the production of textbooks for elementary, secondary, and university students. He was co-editor of three UNESCO publications on mathematics education and collaborated with many colleagues on articles published in international journals, particularly on mathematics education in the Dominican Republic and on the use of technology. In addition, he published articles on pure mathematics.

In 1997 and 1998 he collaborated with Patrick Scott (New Mexico State University) in organizing sessions entitled "Bridge Across the Americas" at the annual meetings of the National Council of Teachers of Mathematics.

In accordance with his professional merits he was a member of numerous academies and scientific societies, such as the American Mathematical Society, Academy of Sciences of the Dominican Republic (founding member), the Inter-American Committee on Mathematical Education, the Mathematical Association of America, the Mathematical Society of the Dominican Republic, and the National Council of Teachers of Mathematics.

Due to his intellectual ability and outstanding work he received many awards and distinctions from prestigious institutions. He received a US Agency for International Development Fellowship to pursue doctoral studies in mathematics in the United States (1969-1973). For his contributions in mathematics education he received (with several collaborators) the Gustavo Mejia Ricart National Science Award (1988) for the work carried out in the study "The Teaching and Learning of Mathematics in the Dominican Republic" and the Manuel de Jesús Peña y Reynoso National Didactics Award 2007-2008, given by the Ministry of Education for the series of textbooks Explore Mathematics.

The administrative life of Dr. Eduardo Luna was also extraordinarily fruitful, both in his native country, the Dominican Republic, and internationally, especially in Latin America. His tireless and unconditional dedication to working for mathematics and mathematics education serves as a role model for future generations. Dr. Luna stood out as a teacher for his solid mathematical knowledge, his masterful pedagogical skills, and the rigor of his classes; and as a human being for his values and warm interpersonal relationships. He was supportive, balanced, peaceful, kind, and helpful; he always exhibited ethically irreproachable behavior; and he was consecrated to his family. He will be missed by all who knew him and remembered for his profound impact on math education in Latin America.

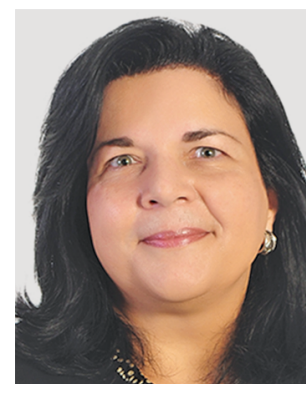

Sarah González de Lora

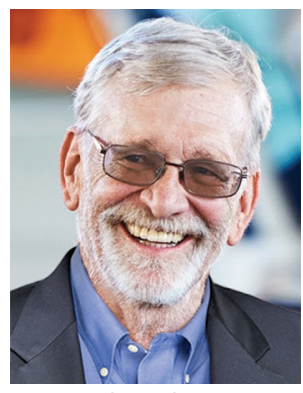

Patrick (Rick) Scott

\section{Credits}

Photo of Sarah González de Lora is courtesy of Sarah González de Lora.

Photo of Patrick (Rick) Scott is courtesy of Patrick (Rick) Scott. 